Article

\title{
The Impact of the Quality of Coal Mine Stockpile Soils on Sustainable Vegetation Growth and Productivity
}

\author{
Nicky M Mushia ${ }^{1,2, *}$, Abel Ramoelo ${ }^{1,3}$ and Kingsley K. Ayisi ${ }^{1}$ \\ 1 Department of Plant Production, Soil Science and Agricultural Engineering, University of Limpopo, \\ Sovenga 0727, South Africa; aramoelo@csir.co.za (A.R.); kwabena.ayisi@ul.ac.za (K.K.A.) \\ 2 Agricultural Research Council, Institute for Soil Climate Water, Pretoria 0001, South Africa \\ 3 Natural Resource and Environment, Earth Observation Group, Council for Scientific and Industrial \\ Research, Pretoria 0001, South Africa \\ * Correspondence: mushian@arc.agric.za; Tel.: +27-12-310-2603
}

Academic Editor: Vincenzo Torretta

Received: 10 April 2016; Accepted: 7 June 2016; Published: 11 June 2016

\begin{abstract}
Stockpiled soils are excavated from the ground during mining activities, and piled on the surface of the soil for rehabilitation purposes. These soils are often characterized by low organic matter (SOM) content, low fertility, and poor physical, chemical, and biological properties, limiting their capability for sustainable vegetation growth. The aim of the study was to evaluate the impact of stockpile soils of differing depth and quality on vegetation growth and productivity. Soils were collected at three different depths (surface, mid, and deep) as well as mixed (equal proportion of surface, mid and deep) from two stockpiles (named Stockpile 1: aged 10 and Stockpile 2: 20 years) at the coal mine near Witbank in the Mpumalanga province of South Africa. Soils were amended with different organic and inorganic fertilizer. A $2 \times 4 \times 5$ factorial experiment in a completely randomized blocked design with four replications was established under greenhouse conditions. A grass species (Digiteria eriantha) was planted in the pots with unamended and amended soils under greenhouse conditions at $26-28^{\circ} \mathrm{C}$ during the day and $16.5-18.5^{\circ} \mathrm{C}$ at night. Mean values of plant height, plant cover, total fresh biomass (roots, stems and leaves), and total dry biomass were found to be higher in Stockpile 1 than in Stockpile 2 soils. Plants grown on soils with no amendments had lower mean values for major plant parameters studied. Soil amended with poultry manure and lime was found to have higher growth rate compared with soils with other soil amendments. Mixed soils had better vegetation growth than soil from other depths. Stockpiled soils in the study area cannot support vegetation growth without being amended, as evidenced by low grass growth and productivity in this study.
\end{abstract}

Keywords: coal mine; stockpile soils; plant parameters

\section{Introduction}

South Africa's economy is highly fossil-fuel-dependent, with the main source of electricity being coal, accounting for about $91 \%$. Apart from the heavy domestic reliance on coal as a source of energy, South Africa is a significant participant in global coal markets. The majority of South Africa's reserves and mines are in the Central Basin, which includes the Witbank (eMalahleni), Highveld, and Ermelo coalfields. South Africa's economically recoverable coal reserves are estimated at between 15 and 55 billion tonnes, and coal production in the Central Basin is likely to peak in the next decade [1].

Surface coal mining requires good and sound rehabilitation practices to re-establish productive land capability and land use after mine closure. The vast majority of Mpumalanga's coal deposits are 
located below high quality productive arable land. Impacts on soil and land associated with surface coal mining can reduce the possibility of re-establishing the pre-mining land capability and productive potential. The result observed in practice, defined as the status quo, is that most surface coal mining companies in Mpumalanga aim to re-establish grazing land capability potential for the end land use option instead of the original arable land capability [2].

Open-cast coal mining activities are leaving an unmistakable footprint on the landscape in the form of altering landscapes form due to open-cast operations and the creation of discard dumps. Valuable agricultural land is being degraded and the long-term productivity of the land is therefore affected [3]. Poor soil management in the operational phase of the mine could limit the re-establishment of pre-mining land-use or another sustainable land capability class post-closure [4-6]. In this study, 10-20-year-old coal mine stockpile soils were used to evaluate their ability to support plant growth and to assess their quality and their fertility status, as those soils will be used for rehabilitation during post mining phase.

Soil is a valuable resource and is the growth medium used by vegetation and for food production. Adequate soil stripping, stockpiling, and management of this resource at a surface coal mine is therefore of utmost importance. Without the management thereof, the post-mining substrate might not only comprise soils [7], nor be able to support a good vegetation cover. Soil generation (pedogenesis) is a lengthy process and takes many years. If stockpiled soil is reapplied quickly after mining, with less compaction from mechanical traction, the production potential of vegetation on the stockpile remains high [8].

Soil is a vital natural resource, constituting a critical controlling component during the early stage of ecosystem development. Soil quality is defined as the capacity of a soil to function within ecosystem boundaries to sustain biological productivity, maintain environmental quality, and promote plant and animal health [9]. Mining activities are invariably associated with the removal of fertile top soil organic layer enriched with vegetation cover and hence has environmental consequences [10].

Open-cast mining severely alters the landscape, which reduces the value of the natural environment in the surrounding land. The land surface is dedicated to mining activities until it can be reshaped and reclaimed. Topsoil stripping and stockpiling is an important and necessary practice of surface coal mining operations, as topsoil forms a critical element for the successful restoration of open pit mines [5]. Topsoil cannot always be placed directly onto mined out land. Therefore, it may be necessary to stockpile the resource for future use [11]. Poor management of topsoil and stockpiles will lower the rehabilitation potential of the soils and increase rehabilitation costs. This, in turn, has an impact on the post-mining land capability and land use once mining has ceased. Improving the fertility and health of the stockpiled soils through amendment is critical for rehabilitation. Currently, there are limited studies of this nature as most of the studies are focused on rehabilitation rather than on good soil management practices during mining operation. The objectives of the study were (1) to evaluate the effect of different depths of stockpile soil on vegetation growth and productivity, and (2) to investigate the capability of different soil amendments enhance stockpile soils to support vegetation growth for rehabilitation purpose in the post-mining period.

\section{Materials and Methods}

\subsection{Locality and Soil Sampling Process}

Bulk soils were sampled from different depths of two soil stockpiles: Stockpile 1 (10 years old) and Stockpile 2 (20 years old) from a coal mine situated approximately $8 \mathrm{~km}$ south of Witbank in the Mpumalanga province of South Africa. Stockpile soils are a mixture of different soil types pilled together in a non-sequential form. There were no visible soil horizons. The depth of each stockpile soil was approximately $400 \mathrm{~cm}$. Sparsely scattered growth of different grass species were observed on the stockpile soils during the time of sampling. The climate of the area can be regarded as having warm, 
moist summers and cool to cold dry winters with frost. On average, $85 \%$ of the annual total rainfall of $750 \mathrm{~mm}$ is received during the growing season (October to March).

\subsection{Greenhouse Experiment: Set up and Sampling}

A $2 \times 4 \times 5$ factorial experiment in a randomized complete block design (RCBD) with four replications was established under greenhouse conditions to minimise any unforeseen variations. The conditions inside the greenhouse were set at a temperature of $26-28{ }^{\circ} \mathrm{C}$ during the day and $16.5-18.5^{\circ} \mathrm{C}$ at night, a relative humidity of approximately $90 \%$, a photoperiod of $8-12-\mathrm{h}$ light $/ 24 \mathrm{~h}$, and the evapotranspiration of 3.5-4.0 mm/day. The indoor temperature was set to mimic the temperature of the surrounding area in summer. The factors studied were as follows: Factor 1 (age of the stockpile soil) at 10 years old and 20 years old; Factor 2 (stockpile soil depth), sampled as follows: surface soil $(0-25 \mathrm{~cm})$; mid soil $(150-200 \mathrm{~cm})$; deep soil $(300-350 \mathrm{~cm})$, and mixed soil (mixture of equal amounts of surface, mid, and deep). The mixed soil treatment was carried out to simulate the condition of the soil during the rehabilitation process at the mines. The third factor was soil amendments, namely: poultry manure, no fertilizer, lime and poultry manure, compost, and lime and mineral fertilizers (NKP). Soils were amended with organic amendments and mineral fertilizers according to fertilizer recommendations for smut finger grass (Digiteria eriantha) using the method by FSSA [12]. One-litre plastic pots $(13 \mathrm{~cm}$ diameter top $\times 11 \mathrm{~cm}$ depth $\times 9.6 \mathrm{~cm}$ diameter at the base) perforated at the base were filled with the amended soils, and seeds of smut finger grass (Digiteria eriantha) were sown in the pots and then grown for 18 weeks in a greenhouse. Poultry manure was air-dried and analysed for nutrient content (Total $\mathrm{N}=5.8 \%, \mathrm{P}=2.5 \%, \mathrm{~K}=2.8 \%, \mathrm{Ca}=12.15 \%$ and $\mathrm{pH}=8.9$ ) [13]. The chicken manure was applied two weeks before planting at a rate of $16 \mathrm{~g} /$ pot, which is equivalent to $3.2 \mathrm{t} / \mathrm{ha}$. A portion of $80 \mathrm{~g} /$ pot or $16 \mathrm{t} /$ ha of compost was also applied two weeks before planting. Statistically, there were no significant differences in soil $\mathrm{pH}$ from the different depths sampled. Lime $\left(\mathrm{CaCO}_{3}\right)$ was applied three months before planting at the rate of $10 \mathrm{~g} /$ pot or $2 \mathrm{t} / \mathrm{ha}$. The reason for applying lime months before planting is to allow enough time for the lime to be release in the soil. Applications of inorganic fertilizers (NPKs) super phosphate $\left[\mathrm{Ca}\left(\mathrm{H}_{2} \mathrm{PO}_{4}\right)_{2}\right] .(10.5 \% \mathrm{P})$ and potassium chloride $[\mathrm{KCl}]$ ( $50 \% \mathrm{~K})$ were made a week after planting [14]. Superphosphate was applied at $0.55 \mathrm{~g} /$ pot or $110 \mathrm{~kg} \mathrm{P} /$ ha, was applied at $0.3 \mathrm{~g} /$ pot or $60 \mathrm{~kg} \mathrm{~K} /$ ha to soils with clay $\%<20$, and $0.39 \mathrm{~g} /$ pot or $78 \mathrm{~kg} \mathrm{~K} / \mathrm{ha}$ to soils with clay $\%>20$. A portion of $0.6 \mathrm{~g} /$ pot or $120 \mathrm{~kg} \mathrm{~N} /$ ha of LAN was applied when plants were 4 weeks old, and the other $0.6 \mathrm{~g} /$ pot was applied when plants were 12 weeks old [15]. Smuts finger (Digiteria eriantha) seeds were subsequently sown in the pots following the soil amendments on 10 January 2015. A total of 160 pots were arranged into $2 \times 4 \times 5$ factorials with four replicates [16]. The decision to use this grass species to evaluate soil fertility and the quality of stockpiled soils was based on the fact that this grass is one of the most commonly used species for post-mine rehabilitation in South Africa. It is also an important source of forage for livestock and wildlife $[17,18]$.

\subsection{Soil Chemical Analysis}

Prior to soil amendment, the sampled soils from surface, mid, deep, and mixed were analysed for physical and chemical properties. The soils were first air-dried and screened through a 2-mm sieve for analysis. A particle size analysis was performed on the $<2 \mathrm{~mm}$ soil fraction using the pipette method Soil Analysis Working Group [13]. Exchangeable cations, cation exchange capacity, soil organic carbon, and exchangeable aluminium $(\mathrm{Al})$, as well as $\mathrm{pH}\left(\mathrm{H}_{2} \mathrm{O}\right)$ were determined according the procedures of Non-Affiliated Soil Analysis Working Group [13]. Textural classes of the soil are as follows. Stockpile 1: surface (sandy clay loam), mid (sandy loam), deep (clay loam) and mixed (loam); Stockpile 2: surface (loamy sand), mid (silt loam), deep (sandy loam), and mixed (sandy loam) (Table 1). Sampled soils were amended according to their respective treatments: (poultry fertilizers and lime, poultry fertilizers, compost, no amendments, and mineral fertilizers and lime. Ten seeds of Digiteria eriantha were sown in each pot and thinned out to a maximum of five plants depending on the number of seeds that 
germinated. Plants were watered four times in a week for the first 6 weeks and thereafter were watered daily until the experiment was completed.

Table 1. Pre-sown soil fertility results.

\begin{tabular}{|c|c|c|c|c|c|c|c|c|}
\hline \multirow[b]{2}{*}{$\ddagger$ Soil Properties } & \multicolumn{4}{|c|}{ Stockpile 1 (10 years) } & \multicolumn{4}{|c|}{ Stockpile 2 (20 years) } \\
\hline & Surface & Mid & Deep & Mix & Surface & Mid & Deep & $\operatorname{Mix}$ \\
\hline $\mathrm{K}$ cmol (+) $\mathrm{kg}^{-1}$ & 0.18 & 0.11 & 0.07 & 0.17 & 0.11 & 0.06 & 0.05 & 0.07 \\
\hline $\mathrm{Ca} \mathrm{cmol}(+) \mathrm{kg}^{-1}$ & 0.74 & 0.47 & 0.33 & 0.68 & 0.54 & 0.77 & 0.72 & 0.66 \\
\hline $\operatorname{Mg~cmol~(+)~} \mathrm{kg}^{-1}$ & 0.45 & 0.42 & 0.27 & 0.49 & 0.27 & 0.58 & 0.28 & 0.46 \\
\hline $\operatorname{Org} C(\%)$ & 0.45 & 0.34 & 0.18 & 0.53 & 0.70 & 0.25 & 0.30 & 0.82 \\
\hline $\mathrm{Al} \mathrm{cmol} \mathrm{(+)} \mathrm{kg-1}$ & 0.72 & 0.84 & 1.12 & 0.69 & 0.79 & 0.77 & 1.07 & 0.93 \\
\hline P-Bray $1\left(\mathrm{mg} \mathrm{kg}^{-1}\right)$ & 8.99 & 7.07 & 6.68 & 8.35 & 6.76 & 6.04 & 4.93 & 7.03 \\
\hline Clay $\%$ & 25.32 & 16.14 & 30.05 & 21.84 & 14.44 & 11.32 & 10.39 & 12.94 \\
\hline Silt \% & 23.10 & 15.90 & 45.68 & 32.01 & 7.38 & 50.19 & 35.66 & 32.18 \\
\hline Sand \% & 51.28 & 67.96 & 24.27 & 45.98 & 78.18 & 38.49 & 53.95 & 54.88 \\
\hline
\end{tabular}

$\ddagger$ Surface soil $(0-25 \mathrm{~cm})(\mathrm{S})$; mid soil $(150-200 \mathrm{~cm})(\mathrm{M})$, deep soil $(300-350 \mathrm{~cm})(\mathrm{D})$, and mixed soil (mixture of equal amounts of surface, mid and deep) (Mx).

\subsection{Data Collection}

The following growth parameters were measured on 30 May 2015 as indicators of vegetative growth: plant height, plant cover, total fresh biomass (roots, stems and leaves), and total dry biomass. According to Maas [19], plant height, plant cover, and plant biomass can be measured as indicators of plant growth. Plant height was measured using measuring tape from the base of the plant to the tip of the topmost leaf of the plant [20]. Plant cover was measured by a visual scoring of the grass cover around the pot [20]. Total fresh biomass was determined at the end of the experiment where the plants were removed from the soil in the pots, and soil on the roots was thoroughly washed off under a tap and a sieve to remove bound soils and retrieve any broken root fraction. The whole plant was weighed to determine total fresh biomass. Grass samples were oven-dried at $60{ }^{\circ} \mathrm{C}$ for $48 \mathrm{~h}$ until a constant weight was reached, and were then weighed with a Mettler PE 6000 balance with $0.01 \mathrm{~g}$ readability for total dry biomass [21].

\subsection{Statistical Analysis}

Data were analysed using a standard procedure for analysis of variance (ANOVA) of a factorial arrangement of a randomised complete block design [22]. Differences between treatment means were separated using the Duncan's Multiple Range Test (DMRT) procedure at 0.05 and 0.01 probability levels. Pearson's correlation coefficient was done to determine the relationships among various variables at a $95 \%$ probability level $(p<0.05)$. All data were analysed using the statistical package, STATISTIX 10.0.

\section{Results}

The mean values of plant parameters at different depths and soil amendments are recorded in Tables 2 and 3, respectively. There were significant differences $(p \leqslant 0.05)$ in plant height, fresh biomass, dry biomass, and plant cover in relation to depth and soil amendments. Mixed soils produced higher mean values for all measured plant parameters. 
Table 2. The effect of different depths of the stockpile on plant parameters.

\begin{tabular}{ccccc}
\hline \multicolumn{5}{c}{ Measured Plant Parameters } \\
\hline † Soils & Height (cm) & Fresh Biomass (g) & Dry Biomass (g) & Plant Cover (\%) \\
\hline MX & $18.72^{\mathrm{a}}$ & $28.33^{\mathrm{a}}$ & $12.96^{\mathrm{a}}$ & $70.80^{\mathrm{a}}$ \\
S & $16.55^{\mathrm{b}}$ & $23.91^{\mathrm{b}}$ & $9.28^{\mathrm{b}}$ & $62.00^{\mathrm{b}}$ \\
M & $14.21^{\mathrm{c}}$ & $22.19^{\mathrm{b}}$ & $8.07^{\mathrm{c}}$ & $61.00^{\mathrm{b}}$ \\
D & $12.85^{\mathrm{d}}$ & $17.34^{\mathrm{c}}$ & $7.34^{\mathrm{c}}$ & $45.90^{\mathrm{c}}$ \\
$\mathrm{p}(\leqslant 0.05)$ & $0.00^{*}$ & $0.00^{*}$ & $0.00^{*}$ & $0.00^{*}$
\end{tabular}

$\ddagger^{\mathrm{a}, \mathrm{b}} \mathrm{c}, \overline{\mathrm{d}}$ indicates significant difference. Means in the same column followed by the different letters are significantly different from each other at the $5 \%$ probability level. ${ }^{*}$ Significant at $p \leqslant 0.05 . \ddagger M X=$ Mixed soil; $\mathrm{S}=$ Surface soil; $\mathrm{M}=$ Mid soil; $\mathrm{D}=$ Deep soil.

Table 3. The effect of soil amendments on plant parameters.

\begin{tabular}{ccccc}
\hline \multicolumn{5}{c}{ Measured Plant Parameters } \\
\hline ‡ Amendments & Height $(\mathbf{c m})$ & Fresh Biomass (g) & Dry Biomass (g) & Plant Cover (\%) \\
\hline NF & $0.28^{\mathrm{e}}$ & $1.80^{\mathrm{c}}$ & $0.44^{\mathrm{e}}$ & $5.30^{\mathrm{d}}$ \\
P + L & $23.47^{\mathrm{a}}$ & $28.33^{\mathrm{a}}$ & $14.55^{\mathrm{a}}$ & $85.16^{\mathrm{a}}$ \\
$\mathrm{NPK}+\mathrm{L}$ & $20.04^{\mathrm{b}}$ & $23.91^{\mathrm{a}}$ & $12.19^{\mathrm{b}}$ & $78.44^{\mathrm{b}}$ \\
$\mathrm{C}$ & $14.53^{\mathrm{d}}$ & $17.34^{\mathrm{b}}$ & $8.97^{\mathrm{d}}$ & $57.50^{\mathrm{c}}$ \\
P & $17.09^{\mathrm{c}}$ & $22.19^{\mathrm{a}}$ & $10.92^{\mathrm{c}}$ & $73.28^{\mathrm{c}}$ \\
$\mathrm{p}(\leqslant 0.05)$ & $0.00^{*}$ & $0.00^{*}$ & $0.00^{*}$ & $0.00^{*}$ \\
\hline
\end{tabular}

$\ddagger \bar{a}, \bar{b}, \mathrm{c}, \mathrm{d}$ indicates significant difference. Means in the same column followed by the different letters are significantly different from each other at the $5 \%$ probability level. * Significant at $p \leqslant 0.05$. $\ddagger$ Height $=$ Plant height Amendments $=$ Soil amendments, NF $=$ No Fertilizer, $\mathrm{P}+\mathrm{L}=$ Poultry manure + lime, $\mathrm{NKP}+\mathrm{L}=$ Inorganic fertilizer + lime, $\mathrm{C}=$ Compost $\mathrm{P}=$ Poultry manure.

Considering the impact of the soil amendment, there was significant improvement in most of the plant parameters measured when soils were amended relative to those sown on unamended soil (Table 3). The application of poultry manure and lime consistently increased height, fresh and dry biomass, as well as plant cover compared with the plants sown on unamend soils. Compost and poultry manure application improved height, fresh biomass, and dry biomass. Plants sown on soil with no fertilizer showed a significantly low growth rate. Among the different soil amendment treatments, the poultry manure and lime combination and the lime and inorganic fertilizer combination were superior in terms of the parameters measured.

Figures 1 and 2 presents the combined effects of soil depth and amendments on plant height and total dry biomass. The results show that there was no significant difference $(p<0.05)$ in plant height at different depths when the grass was sown on soils with no fertilizer (Figure 1). The results in Figure 1 also show a significant difference in plant height in response to soil depths when soil was amended with lime and poultry, compost, lime and inorganic fertilizer, and poultry manure. Plants sown on soil with no fertilizer showed no significant difference $(p<0.05)$ for dry biomass among different depths of stockpile (Figure 2). Correlation statistics indicated significant correlations among all measured plant parameters (Table 4).

Table 4. Correlations coefficients $\left(\mathrm{r}^{2}\right)$ between selected parameters measured from plants parameters grown on stockpile soils.

\begin{tabular}{ccccc}
\hline & Height & Fresh Biomass & Dry Biomass & Cover \\
\hline Height & 1.00 & 1.00 & \\
Fresh biomass & $0.97^{*}$ & $0.99^{*}$ & 1.00 & \\
Dry Biomass & $0.96^{*}$ & $0.97^{*}$ & $0.95^{*}$ & 1.00 \\
Cover & $0.93^{*}$ & &
\end{tabular}




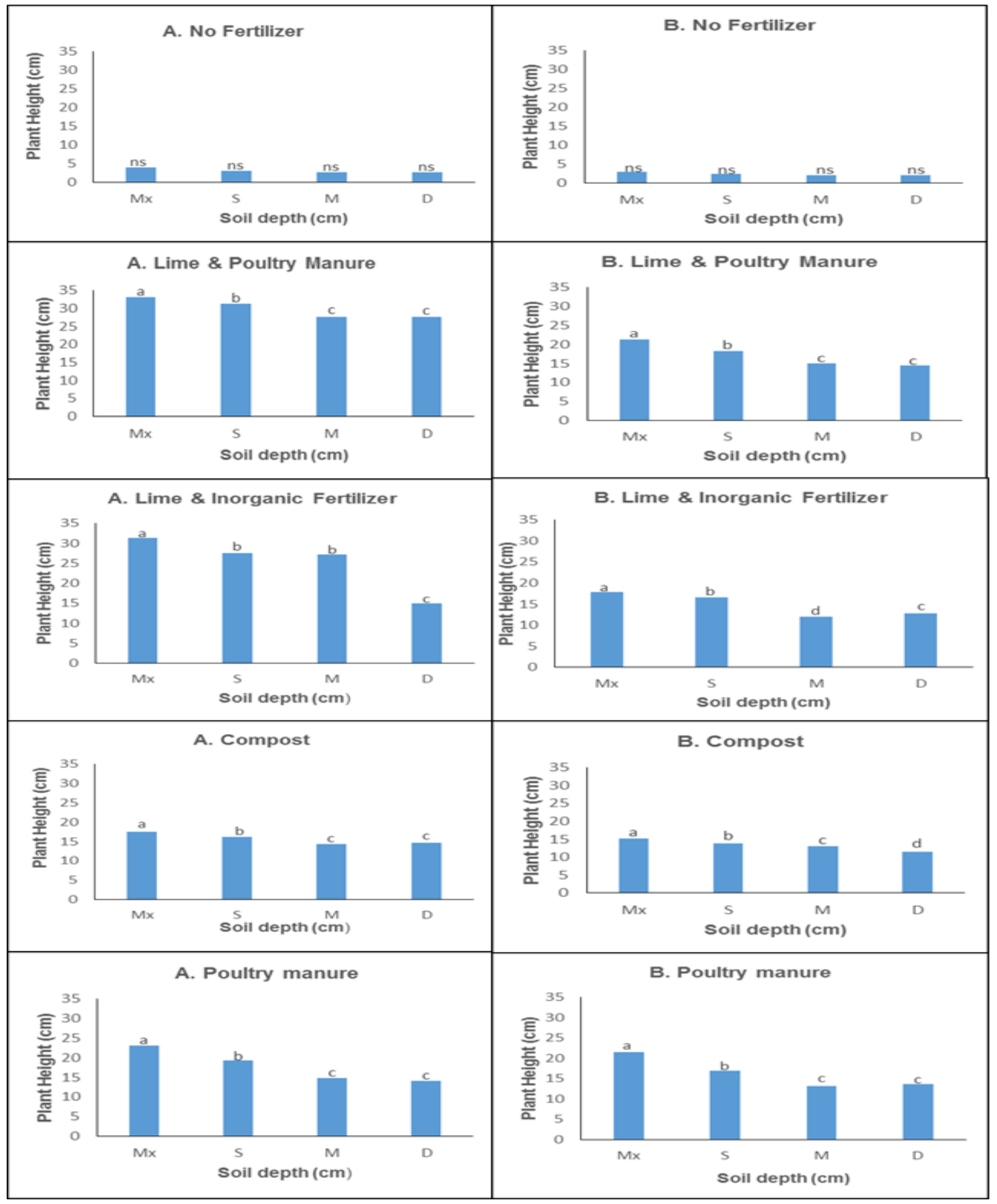

Figure 1. Effect of soil depth and amendments on plant height. a, b, c indicates significant difference. Means with the same letter are not significantly different from each other at the $95 \%$ probability level. * Significant at $p \leqslant 0.05$. A = Stockpile 1, B = Stockpile. $\ddagger$ MX = Mixed soil; $\mathrm{S}=$ Surface soil; $\mathrm{M}=$ Mid soil; $\mathrm{D}=$ Deep soil. 


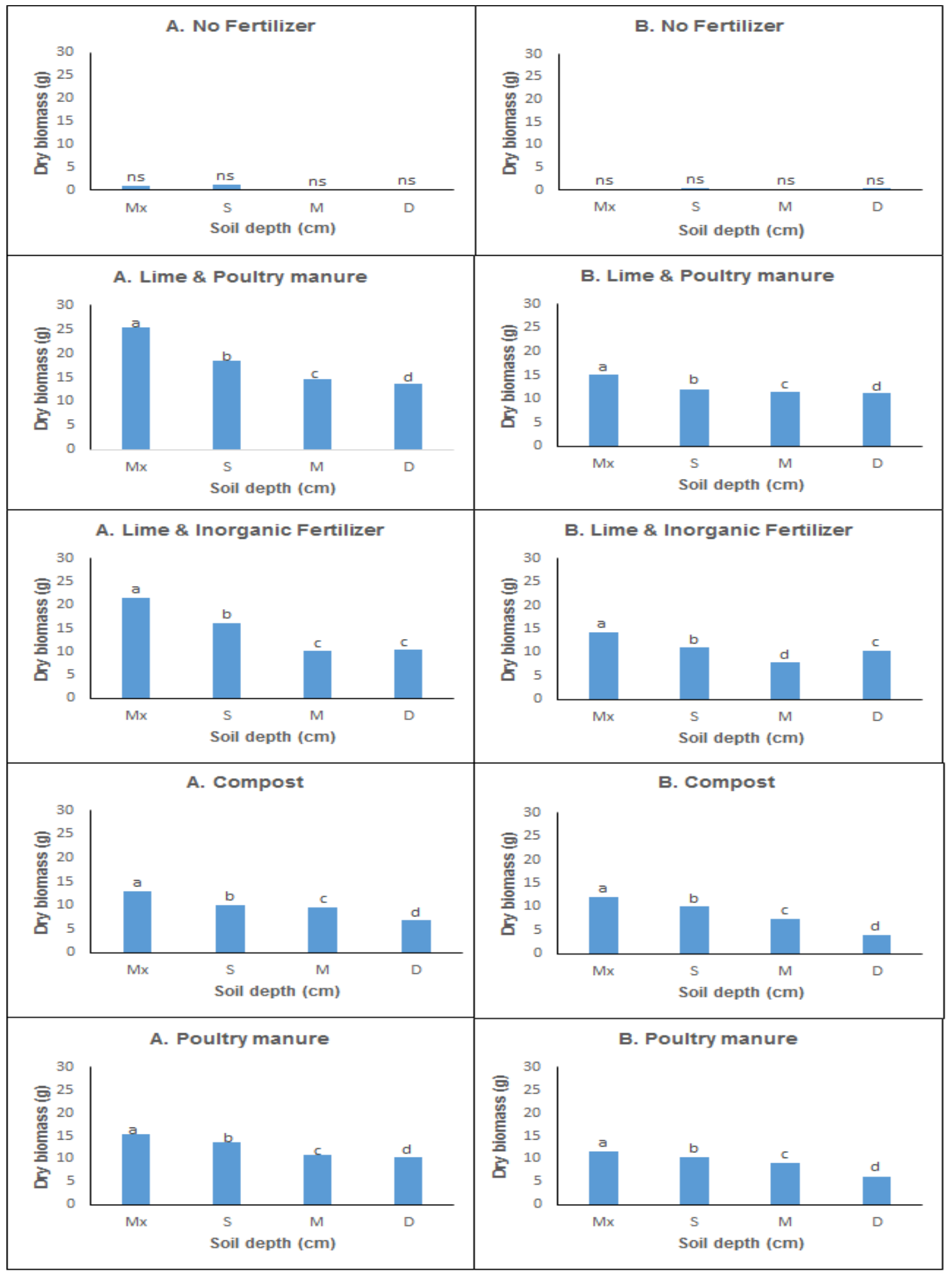

Figure 2. Effect of soil depth and amendments on total dry biomass. a, b, c indicates significant difference of mean. Means with the same letter are not significantly different from each other at the $95 \%$ probability level (e.g., a, b). * Significant at $p \leqslant 0.05$. A = Stockpile 1, B = Stockpile 2. $\ddagger \mathrm{MX}=$ Mixed soil; $\mathrm{S}=$ Surface soil; $\mathrm{M}=$ Mid soil; $\mathrm{D}=$ Deep soil. 


\section{Discussion}

\subsection{Effect of Soil Stockpile Age on Vegetation Growth}

Stockpiling of soil mounds during mineral extraction has been shown to affect the chemical and physical properties of the soil $[23,24]$. Plant parameters measured from plants grown on soils from Stockpile 1 (age 10 years) produced higher mean values compared with those planted on Stockpile 2 (age 20 years). This can be attributed to the fact that, when soils are stored for a long time, nutrients released by microbiological activity are continually lost due to leaching and erosion, the nutrient cycle is broken down, and the soil ultimately become unproductive $[4,25]$. According to Kundu and Ghose [26], as the age of soil stockpile increases, the concentrations of suitable plant growth nutrients in soil gradually decrease.

\subsection{The Effect of Stockpile Soil Depth on Plant Parameters}

Mixed soils tend to have higher vegetation growth as indicated by measured parameters than all other soils from different depths (surface, mid and deep). Higher vegetation growth shows that mixing stockpile soils can improve productivity of the soil. There was no significant increase in organic carbon percentage, soil $\mathrm{pH}$, or other soil elements, and there was a decrease in exchangeable aluminum when the soils were mixed. Higher mean values of all plant parameters measured on plants grown on mixed soils can be attributed to a change in soil texture, which affects other physical properties such as water availability, infiltration rate, and aeration and to some extent chemical properties $[27,28]$. The mixed soil of Stockpile 1 was classified as loam soil (Table 1). According to NRCCA [29] and Shaxson and Barber [30], the average water-holding capacity (inch/foot) of loam soil is two times higher than that of sandy clay loam (surface soil). The same applies to sandy loam and loamy sand. Sandy loam soil has a water-holding capacity two times higher than that of loamy sand [29,30]. Stockpile 2 mixed soil was classified as sandy loam, whereas surface soil was classified as loamy sand. According to Bierhuizen [31], soil with a high water-holding capacity are favorable for plant growth, since plants receive enough water for cell elongation, leaf expansion, and fresh biomass.

Deep and mid soils revealed low vegetation growth, as most plant parameters were statistically lower compared with mixed and surface soils. According to Harris and Birch [32], when soil is stockpiled in piles that are more than a meter deep, chemical effects such as accumulation of ammonium and anaerobic conditions occur in the soil at the base of the pile. Mid and deep soils used in this study were stockpiled deeper than $1 \mathrm{~m}$. Deep soils in this study were found to have an aluminum content of more than $1.0 \mathrm{cmol}(+) \mathrm{kg}^{-1}$. A high concentration of $\mathrm{Al}^{3+}$ content in the soil inhibit shoot growth by inducing deficiency in $\mathrm{Ca}, \mathrm{Mg}$, and $\mathrm{P}$, and hormonal imbalances in plants [33]. Tate and Klem [34] concluded that the depth of stockpiles should be restricted to the rooting depth of covering vegetation and further indicated that, if plant cover can be maintained with roots extending throughout the depth of the stockpile, nutrient cycling processes and microbial activity can continue while the stockpile is stored. Soils used in the experiments was stockpiled to a maximum depth of approximately $4 \mathrm{~m}$. There was a higher plant growth rate in surface soils in both stockpiles as compared to mid soils and deep soils that can be attributed to a high level of organic carbon on surface soils. According to NSW [35], microbes decompose organic matter on the soils releasing nitrogen, phosphorus, and other elements for use by plant roots. The report further indicates that soil organic carbon decreases with soil depth and that disturbed soils lose more labile organic carbon than well-managed soils.

\subsection{Effect of Soil Amendments on Vegetation Growth}

Soils disturbed by surface mining are always hostile to planted tress due to changes in physical and chemical properties [3]. Surface coal mining results in the degradation of soil physical properties, a significant loss of organic matter, and nutrients and hence diminishes soil productivity [36]. Restoring the soil productivity and the establishment of sustained vegetative cover are primary objectives of mine soil reclamation. The soil used in the study was acidic, with $\mathrm{pH}$ ranging from 5.2-5.9. This can 
be due to the high rainfall of the area, which resulted in the losses of exchangeable bases from the soil with the consequent effect of acidification of the soil [7].

Most of the stockpile soils had deficiencies in essential soil elements. This confirms the findings by Ussiri and Lal [37] that physical and chemical properties of mine soils tend to inhibit soil-forming processes and plant growth. This is usually due to a lack of nutrients associated with SOM, including nitrogen $(\mathrm{N})$ and phosphorus $(\mathrm{P})$. Soils with no amendments had a low plant growth rate compared with soils amended with fertilizers. This is consistent with the finding of Mohapatra and Goswami [38] that stockpile soil tends to have reduced essential nutrients for plant absorption.

The mean values of plant parameters measured in this study increased with the addition of soil amendments. Poultry manure and lime tend to have higher mean values for all measured plant parameters in both stockpile soils. This confirms the findings in $[39,40]$ that showed that organic waste applications raise soil $\mathrm{pH}$ and increase plant growth in acid soils. According to Stevenson and Vance [41], manures contain humic-type substances with many functional groups such as carboxyl and phenolic groups that are able to consume protons at their natural $\mathrm{pH}$ values. These substances are formed during the decomposition process and are relatively stable against further decomposition. Their capacity to consume protons therefore controls the buffer characteristics of these materials and thus their ability to neutralize soil acidity. The addition of agricultural lime increases soil pH, and, at $\mathrm{pH} 5.5$, most of toxic elements bind to other elements in the soil solution and reduce the availability for plant uptake [42]. When soils were amended with lime and inorganic fertilizer, vegetation growth parameters increased, but not similarly to poultry manure and lime. According to Ayeni and Adetunji [43], poultry manure has $\mathrm{Ca}$ and $\mathrm{Mg}$, which are not usually supplied by inorganic fertilizer except as impurities. The studies by Adediran and Ojeniyi [44] and Adediran et al. [45] reported that poultry manure was composed of micro- and macronutrients. Because of the more balanced nutrition given by poultry manure, their studies found that poultry manure at $10 \mathrm{t} \cdot \mathrm{ha}^{-1}$ gave a higher maize yield than NPK fertilizer at $400 \mathrm{~kg} \cdot \mathrm{ha}^{-1}$. In this study, $3.2 \mathrm{t} \cdot \mathrm{ha}^{-1}$ of poultry manure yielded high vegetation growth than a combination of applications of $240 \mathrm{~kg} \cdot \mathrm{N} \cdot \mathrm{ha}^{-1}, 110 \mathrm{~kg} \cdot \mathrm{P} \cdot \mathrm{ha}{ }^{-1}$, and $78 \mathrm{~kg} \cdot \mathrm{K} \cdot \mathrm{ha}^{-1}$.

Poultry manure normally adds cations in the soils (especially Ca). The addition of large quantities of cations to a soil results in the accumulation of cations in soil solution with a consequent displacement of $\mathrm{H}^{+}$from exchangeable sites into solution [46]. The displacement of $\mathrm{H}^{+}$from exchangeable sites into solution contributes to the availability of essential nutrients for plant absorption. Poultry manure alone has a good influence on plant parameters compared with compost. Poultry manure has a high Ca content, which contributes to high $\mathrm{CaCO}_{3}$ content of the manure, which explains why poultry manure was an effective amendment for increasing vegetation growth. The addition of compost to soils increased productivity better than no fertilizer application at all. Compost increases soil $\mathrm{pH}$ and adds nutrients to the soil [47]. The addition of compost improves the cation exchange capacity of soils, enabling them to retain nutrients longer. It will also allow crops to more effectively utilize nutrients while reducing nutrient loss by leaching [48]. Wong et al. [49] found that the addition of compost to acid soils increases the soil $\mathrm{pH}$ and ameliorates soil acidity. They attributed this effect primarily to the proton consumptive ability of the added organic materials.

\section{Conclusions}

- The depth of the stockpile affects the quality of the soil at replacement. Soil stored at depths higher than $1 \mathrm{~m}$ had an effect on plant growth. They yielded low mean values. When the soils were mixed (as would happen in the rehabilitation process), they generally produced better results than any of the three soils sampled separately at different depths.

- Without the addition of lime and fertilizers, stockpiled soil could not support vegetation growth and productivity, as there was a very low plant growth rate observed. Poultry manure and lime is essential for the plant growth and productivity of stockpile soils.

- Soil amendments, particularly agricultural lime and mineral fertilizers, help in reducing soil nutrient stress, but are often expensive, which will make soil rehabilitation difficult. 
Since the process of stockpiling and reapplying stockpiles involves additional expenses and effort, a careful analysis of results from sites with stockpile soil applications would provide the necessary information for a cost-benefit analysis and would indicate possibilities for improvement in the efficiency of the process of stockpiling.

Acknowledgments: We acknowledge financial support from the Coaltech project, Agricultural Research Council, the National Research Fund, and the University of Limpopo. We further extend gratitude to Garry Paterson as a project leader for the Coaltech stockpiles project for allowing the study to use the data, and the Coaltech stockpile project team for assisting with data collection.

Author Contributions: Nick Mushia conceived and designed the study, participated in field data collection and statistical analysis, and authored the paper. Abel Ramoelo supervised the study and edited the paper. Kingsley Ayisi supervised the study and edited the paper.

Conflicts of Interest: The geographical location of the study site and name of the mine could not be used in this study due to a confidentiality clause of the mining company.

\section{References}

1. The Bench Marks Foundation. South African Coal Mining: Corporate grievance mechanisms, community engagement concerns and mining impacts. 2014. Available online: http://www.bench-marks.org.za/ research/policy_gap_9.pdf (accessed on 11 May 2015).

2. Botha, I. Aquaponics as a productive rehabilitation alternative in the Mpumalanga Highveld coalfields. In Magister in Environmental Management Mini-Dissertation; University of the Free State: Bloemfontein, South Africa, 2014.

3. Chodak, M.; Niklinska, M.; Sliwinska, E. Chemical and biological properties of sandy mine soils afforested with scots pine and silver birch. Pol. J. Environ. Stud. 2011, 20, 285-291.

4. Ghose, M.K. Effect of opencast mining on soil fertility. J. Sci. Ind. Res. 2004, 63, 1006-1009.

5. Ghose, M.K. Management of topsoil for geo-environmental reclamation of coal mining areas. Environ. Geol. 2001, 40, 1405-1410.

6. Strohmayer, P. Soil Stockpiling for Reclamation and Restoration Activities after Mining and Construction; University of Minnesota: Minneapolis, MN, USA, 1999; pp. 271-278.

7. Mentis, M.T. Restoring native grassland on land disturbed by coal mining on the Eastern Highveld of South Africa. South Afr. J. Sci. 2006, 102, 193-197.

8. Thomas, D.; Jansen, I. Soil development in coal mine spoils. J. Soil Water Conserv. 1985, 34, 439-442.

9. Doran, J.W.; Parkin, T.B. Defining and assessing soil quality. In: Defining soil quality for a sustainable environment. Soil Sci. Am. J. 1994, 35, 3-21.

10. Fox, J.E.D. Rehabilitation of mined lands. Forest ABS 1984, 45, 565-595.

11. Chamber of Mines South Africa and Coaltech Research Association. Guidelines for the Rehabilitation of Mined Land; Chamber of Mines South Africa and Coaltech Research Association: Johannesburg, South Africa, 2007; Available online: https:/ / commondatastorage.googleapis.com/comsa/Guidelines\%20for\%20the\% 20rehabilitation\%20of\%20mined\%20land\%20Nov07.pdf (assessed on 25 March 2015).

12. FSSA. Fertilizer Handbook, 6th ed.; FSSA: Pretoria, South Africa, 2007.

13. Non-Affiliated Soil Analysis Working Group. Handbook of Standard Soil Testing Methods for Advisory Purposes; Soil Science Society of South Africa: Pretoria, South Africa, 1990.

14. Unagwu, B.O.; Asadu, C.L.A.; Ezeaku, P.I. Maize response to organic and inorganic (Poultry manure) and inorganic fertilizers (NPK 15-15-15) at different soil pH levels. Int. J. Environ. Sci. 2012, 1, 126-134.

15. Huang, W.Y.; Hunsen, L.; Uri, N.D. The application timing of nitrogen fertilizers. Water Air Soil Pollut. 1994, 73, 189-211. [CrossRef]

16. Morrison, M.L. Wildlife Study Design; Springer: Berlin, Germany, 2001.

17. Truter, W.F.; Rethman, N.F.G.; Potgieter, C.E.; Kruger, R.A. Re-Vegetation of Cover Soils and Coal Discard Material Ameliorated with Class F-Fly Ash. In Proceedings of the 2009 World Coal Ash Conference, Lexington, KY, USA, 4-7 May 2009.

18. Rethman, N.F.G.; Tanner, P.D. Sustainability of grassland on rehabilitated strip mines in South Africa. 1995. Available online: http://pdf.library./Sudbury95/Rehabilitation/PDF (accessed on 3 March 2013). 
19. Maas, S.J. Estimating cotton canopy ground cover from remotely sensed scene reflectance. Agron. J. 1998, 90, 384-388. [CrossRef]

20. BBIRD Grassland Protocol. Measuring vegetation. Available online: www.umt.edu/GRASSLND.pdf (accessed on 29 April 2013).

21. Ansah, T.; Osafo, E.L.K.; Hansen, H.H. Herbage yield and chemical composition of four varieties of Napier (Pennisetum purpureum) grass harvested at three different days after planting. Agric. Biol. J. North Am. 2010, 1, 923-929. [CrossRef]

22. Gomez, K.A.; Gomez, A.A. Statistical Procedure for Agricultural Research. In An International Rice Research Institute Book; Wiley-Interscience Publication: New York, NY, USA; Chichester, UK, 1984.

23. Johnson, D.B.; Williamson, J.C.; Bailey, A.J. Microbiology of soils at opencast coal sites: Short and long term transformations in stockpiled soils. J. Soil Sci. 1991, 42, 1-8. [CrossRef]

24. Harris, J.A.; Birch, P.; Short, K.C. Changes in the microbial community and physico-chemical characteristics of top soils stockpiled during opencast mining. Soil Use Manage. 1989, 5, 161-168. [CrossRef]

25. De, S.; Mitra, A.K. Reclamation of mining-generated wastelands at Alkusha-Gopalpur abandoned open cast project, Ranging Coalfield, eastern India. Environ. Geol. 2002, 43, 39-47. [CrossRef]

26. Kundu, N.K.; Ghose, M.K. Shelf Life of Stock-piled Topsoil of an Open Cast Coal Mine. Environ. Conserv. 1997, 24, 24-30. [CrossRef]

27. Garg, J.; Kumar, A. Effect of different soil types on growth and productivity of Euphobia Lathyris L. A hydrocarbon yielding plant. Int. J. Life Sci. Pharm. Res. 2012, 2, 164-173.

28. Rice, T.J. Importance of soil texture to vineyard management. Available online: http://www.practicalwinery. com/marapr02p22.htm (accessed on 10 May 2016).

29. NRCCA. Soil Hydrology AEM; Cornell University: Ithaca, NY, USA, 2010; Available online: https://nrcca. cals.cornell.edu/soil (accessed on 1 June 2016).

30. Shaxson, F.; Barber, R. Optimizing Soil Moisture for Plant Productivity: The Significant of Soil Porosity; Food and Agricultural Organisation of the United Nations: Rome, Italy, 2003.

31. Bierhuizen, J.F. Plant growth and soil moisture relationship. In Proceedings of the Unesco-Spain Symposium on Plant-Water Relationship in Arid and Semi-Arid Conditons, Madrid, Spain, 26-30 September 1959.

32. Harris, J.A.; Birch, P. Soil microbial activity in opencast coal mine restorations. Soil Use Manage. 1989, 5, 155-160. [CrossRef]

33. Roy, B.; Bhadra, S. Effects of toxic levels of aluminium on seedling parameters of rice under hydroponic culture. Rice Sci. 2014, 21, 217-223. [CrossRef]

34. Tate, R.L., Klem, D.A., Eds.; Soil Reclamation Processes: Microbiological Analyses and Applications; Marcel Dekker, Inc.: New York, NY, USA, 1985.

35. NSW. A Farmer's Guide to Increasing Soil Organic Carbon under Pastures. Available online: http:/ / www.dpi.nsw.gov.au/_data/assets/pdf_file/0014/321422/A-farmers-guide-to-increasingSoil-Organic-Carbon-under-pastures.pdf (assessed on 20 March 2015).

36. Akala, V.A.; Lal, R. Soil organic carbon pools and sequestration rates in reclaimed mine soils in Ohio. J. Environ. Qual. 2001, 30, 2098-2104. [CrossRef] [PubMed]

37. Ussiri, D.A.N.; Lal, R. Carbon sequestration in minesoils reclamation. Crit. Rev. Plant Sci. 2005, 24, $151-165$. [CrossRef]

38. Mohapatra, H.; Goswami, S. Impact of coal mining on soil characteristics around Ib river coalfield, Orissa, India. J. Environ. Biol. 2012, 33, 751-756. [PubMed]

39. Haynes, R.J.; Mokolobate, M.S. Amelioration of AI toxicity and P deficiency in acid soils by additions of organic residues: A critical review of the phenomenon and the mechanisms involved. Nutr. Cycl. Agroecosys. 2001, 59, 47-63. [CrossRef]

40. Hue, N.V. Correcting soil acidity of a highly weathered Ultisol with chicken manure and sewage sludge. Commun. Soil Sci. Plant Anal. 1992, 23, 241-264. [CrossRef]

41. Stevenson, F.J.; Vance, G.F. Naturally occurring aluminium-organic complexes. In The Environmental Chemistry of Aluminium; Sposito, G., Ed.; CRC Press: Boca Raton, FL, USA, 1989; pp. 117-145.

42. Vogel, W.G. A Guideline for Revegetating Coal Mine Soils in the Eastern United States; General technical Report NE-68. United States Department of Agriculture: Washington, DC, USA, 1981. 
43. Ayeni, L.S.; Adetunji, M.T. Integrated application of poultry manure and mineral fertilizer on soil chemical properties, nutrient uptake, yield and growth components of maize. 2010. Available online: http://www. sciencepub.net/nature/ns0801/06_2101_leye_ns0801_60_67.pdf (accessed on 12 August 2015).

44. Adeniyan, O.N.; Ojeniyi, S.O. Comparative effectiveness of different levels of poultry manure with NPK fertilizer on soil fertility, nutrient uptake and uptake of maize. Moor J. Agric. Res. 2006, 4, 194-197.

45. Adediran, J.A.; Taiwo, I.B.; Sobulo, R.A. Comparative nutrients level of some solid organic wastes and their effect on tomato (Lycopersicum esculentus) yield. Afr. Soil. 2005, 33, 100-113.

46. Samuel, L.T.; Welner, I.N.; James, D.B. Soil Fertility and Fertilizers, 4th ed.; Macmillan: New York, NY, USA, 1985; Available online: http://www.worldcat.org/title/soil-fertility-and-fertilizers-an-introduction-tonutrient-management/oclc/898408100?referer=di\&ht=edition (assessed on 10 February 2016).

47. Chang, E.H.; Chung, R.S.; Tsai, Y.H. Effect of different application rates of organic fertilizer on soil enzyme activity and microbial population. Soil Sci. Plant Nutr. 2007, 53, 132-140. [CrossRef]

48. USCC. Compost and its benefits. 2001. Available online: www.bae.ncsu.edu/composting.pdf (accessed on 11 August 2015).

49. Wong, M.T.F.; Nortcliff, S.; Swift, R.S. Method for determining the acid ameliorating capacity of plant residue compost, urban waste compost, farmyard manure and peat applied to tropical soils. Commun. Soil Sci. Plant Anal. 1998, 29, 2927-2937. [CrossRef]

(C) 2016 by the authors; licensee MDPI, Basel, Switzerland. This article is an open access article distributed under the terms and conditions of the Creative Commons Attribution (CC-BY) license (http:/ / creativecommons.org/licenses/by/4.0/). 